\title{
インテリジェントセンサー講座 (II)
}

\author{
自動車用インテリジェントセンサー
}

\section{1. まえがき}

一つの良いセンサー，良いアクチュエーターがシス テムの機能やポテンシャルを決める例は数多くある。 パソコン入力のマウス, ファジー洗濯機の污れ検知セ ンサー, オートフォーカスカメラの自動焦点検知機構, P O S (Point of Sales) 機器のバーコードリーダ, 自動水洗式トイレの赤外線センサー等, 便利なもの, 使い易い機器には優れたセンサーの応用がある。

自動車の世界に拉いても同様で，日本や米国におけ る厳しい排出ガス規制をクリアする為の最も重要な技 術である E F I (電子制御燃料噴射装置)フィード バックシステムは， $\mathrm{O}_{2}$ センサー（酸素センサー）が あって初めて可能となった。近年話題のエアバッグシ ステムも，優れた Gセンサー（衝突時の車体減速度を 検知するセンサー）によるところが大である。また最 近では P Z T の高速応答性や高耐圧縮性を利用したピ エゾT E M S （ピエゾの圧電効果を利用したサスペン ション制御システムで，ピエゾの持つ高速応答性を用 いてシステムのレベルアップを図っている) 等もその 例である。

自動車用インテリジェントセンサーの話をする前 に,”インテリジェントセンサーとは”について考え てみたい。これまでにもインテリジェントセンサーに 関する論文は数多くある。その中で代表的な概念は図 1 のような考え方のようである。即ちセンサーに信号 調整機能や A / D 変換機能が付加されてゆき, 最終的 にはマイクロプロセッサー機能も取り込んだものであ る。もちろんこの考え方に異論はないが, もう少し視 点を変えて考えてみたい。

一般に一つのシステムを設計する場合, 最適な入力 変数の選択とそれを処理する手段が必要である。シス テムの目標に応じてそれぞれの入力变数を直接検出す

東富士研究所 裾野市御宿 1200

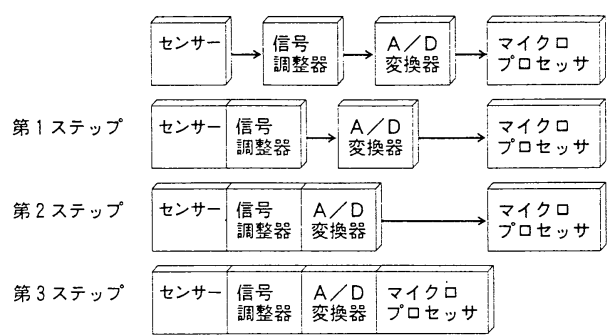

図1 インテリジェントセンサーの発展過程

ることが望ましいが，センサー技術の制約によって直 接検出できない場合も多い。このような時は，多くの 関連する入力情報から必要な変数を間接的に推定して いる(ソフトセンシング)。

ここでは, インテリジェントセンサーとは, 後処理 に有利な状態に変換して出力するセンサーとするが, 従来ソフトセンシングでしか検知できなかった状態量 を，新しい機能性材料，マイクロマシニング技術，信 号処理技術等を用いて直接的にたくみに検知する技術 により可能としたセンサーも含めて考える。

\section{2. 自動車用センサーのインテリジェント化の現状}

表 1 はトヨ夕から量産化されたシステムおよびセン サーの一例を示すものである。自動車用センサーは高 信頼性，使用環境条件への適合性，長期間耐久性，小 型軽量化，低コス卜化等，種々の矛盾する要求を満た す必要がある。そのため, 確立された技術を使ったも のが多かったが, 最近では燃費向上や排出ガス低減, 安全性向上や多様化するユーザニーズへのキメ細かな 対応等, 要求の高度化と, 半導体技術, 材料進歩等, シーズ側の進歩とが相まってかなり変化して来ている。 2.1 エンジン・駆動分野

この分野は自動車におけるセンサーの発達に最も大 きな影響を与えた分野である。エンジンの燃料制御に 
表 1 トヨタ車でのセンサーの歴史

\begin{tabular}{|c|c|c|c|}
\hline 年代 & エンジン・駆動 & シャシ・走行 & ボデー・艤装 \\
\hline $\begin{array}{l}80 \\
\text { 以前 }\end{array}$ & 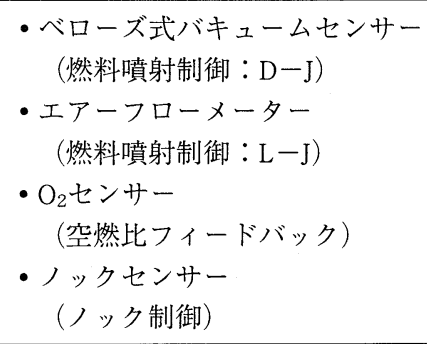 & $\begin{array}{c}\text { ・後輪スピードセンサー } \\
\text { (2 輪E S C ) }\end{array}$ & $\begin{array}{l}\text { ・C d s センサー } \\
\text { (コンライト) } \\
\text { ・ブレーキパットライニング } \\
\text { ウェアセンサー } \\
\text { (O K モニタ) } \\
\text { ・日射センサー } \\
\text { (マイコンオートエアコン) }\end{array}$ \\
\hline $\begin{array}{c}81 \\
1 \\
' 85\end{array}$ & $\begin{array}{l}\text { ・半導体式バキュームセンサー } \\
\quad(\mathrm{E} F \mathrm{~F} \text { I - D ) } \\
\text { ・リーンミクスチャセンサー } \\
\quad \text { (希薄燃烧制御) } \\
\text { ・着火時期センサー } \\
\quad\left(\begin{array}{l}\text { 着火フィードバック } \\
\text { ディーゼル制御 }\end{array}\right) \\
\text { ・カルマン式エアーフローメーター } \\
\quad \text { (燃料噴射制御) }\end{array}$ & $\begin{array}{l}\text { ・ハイトコントロールセンサー } \\
\quad \text { (車高制御) } \\
\text { ・ステアリングセンサー } \\
\quad \text { (T E M S ) }\end{array}$ & $\begin{array}{l}\text { ・地磁気センサー } \\
\text { (ナビデーション) } \\
\text { ・ウルトラソニックセンサー } \\
\text { (バックソナー) } \\
\text { ・スモークセンサー } \\
\text { (オートエアピュリファイア) } \\
\text { ・チルトポジションセンサー } \\
\text { ・テレスコポジションセンサー } \\
\text { (プリセットステアリング) }\end{array}$ \\
\hline$\stackrel{2}{86}$ & & $\begin{array}{l}\text { ・後輪舵角センサー } \\
\quad \text { (デュアルモード 4 W S ) } \\
\text { ・加速度センサー } \\
\text { ・車高センサー〔ホール素子・MRE }] \\
\text { ・圧カセンサー〔半導体 }] \\
\text { (アクティブサス) } \\
\text { ・ピエゾセンサー } \\
\text { (ピエゾT E M S ) }\end{array}$ & $\begin{array}{l}\text { ・雨滴センサー } \\
\quad \text { (オートワイパ) } \\
\text { ・エアバッグセンサー } \\
\quad(\text { 電気式エアバッグ })\end{array}$ \\
\hline
\end{tabular}

おいては1970年代前半よりキャブレータ制御方式から E F I 制御方式となり，その制御も1980年代前半から アナログ方式からマイクロコンピューターを用いた ディジタル方式となって，センサー技術も大幅に変化 した。

キャブレータ制御方式では燃料はポートの位置やノ ズルの径，しぼり等のメカニカルな要素を用いて， オートチョーク, ファーストアイドル, アイドル時増 量や加速増量，減速時燃料カットなどの仕様をマッチ ングしており，巧みなメカニズムの中に仕様（システ ムソフト）が入り込んでいた。EF I 化によってエン ジンの種々の状態が，それぞれ専用のセンサーによっ て検出され，E C Uが制御ロジックを演算してアク チュエータ（インジェク夕）が㗢く(噴射する) とい うように機能を分担するようになった（図 2 )。

この変化はセンサーのインテリジェント化という面 から眺める時, 多少面白い変化をしていると言える。

キャブレー夕は，複雑な制御仕様を極めて巧みにメ

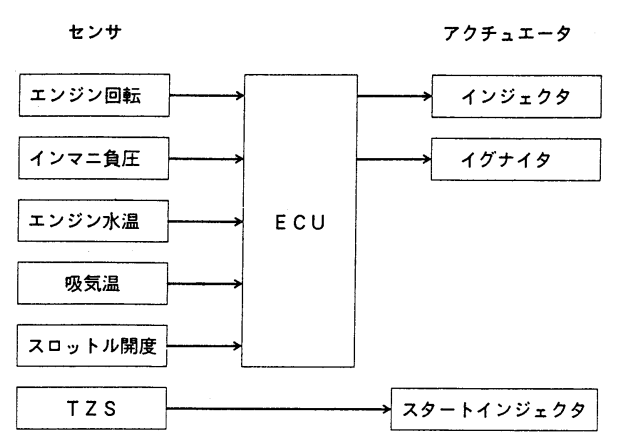

図 2 初期の EFI のシステムの構成

カニカルに実現したインテリジェントセンサーノアク チュエータである。このキャブレータに取って代わっ た E F I においても, 次に述べる T Z S (Thermo Zeit Schalter）のような優れたインテリジェントセン サーもあるが，図 2 に示す如く多くのセンサーは単に ある物理量や状態を測定するだけになっていた。これ 
はセンサー技術またはセンサーのインテリジェント化 に関しては退歩的現象とも言える。それはキャブレー タのインテリジェンスが何十年もかかってそのインテ リジェント化を進歩させたことを考えるとき，E F I 用センサーのインテリジェント化の為にもそれなりの 時間が必要なのかも知れない。

E F I の始動用燃料量制御に用いられる T Z S の構 造は図 3 のようになっており, その代表的な特性は図 4である。エンジンの冷却水温が低い時は燃料の気化 率が悪い為, 多量の燃料 (始動増量) が必要である。

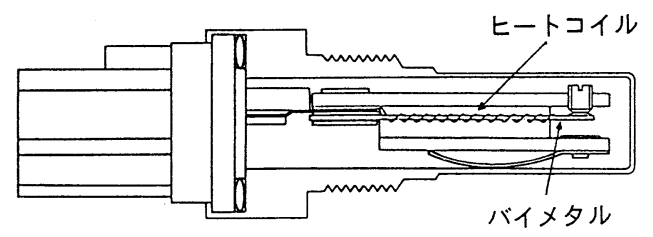

図 3 TZS 構造

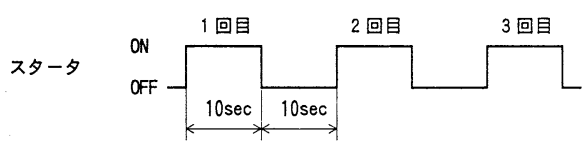

作動パターン

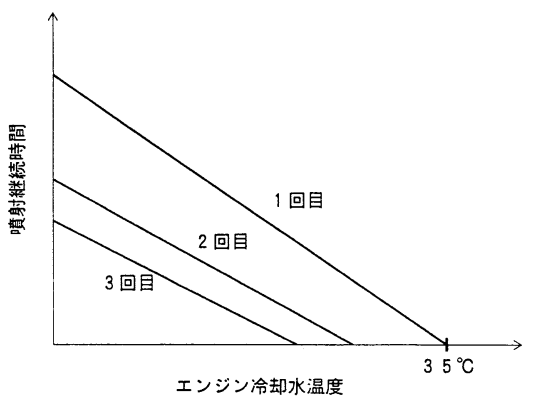

図 4 TZS の噴射継続時間特性
しかし，ある程度以上の温度（この場合 $35^{\circ} \mathrm{C}$ ）では オーバリッチとなり始動性が悪化するのを防止する為, 始動増量を中止させている。また，始動を繰り返す場 合, 2 回目, 3 回目は始動増量を徐々に少なくする必 要がある。この様な複雑な要求特性を, マイクロコン ピューター等一切使わずに巻線の発熱特性, バイメ夕 ルの温度特性, ケースへの放熱特性等の組合せで実現 させている。これ等もまさにインテリジェントセン サー（一部アクチュエータの機能もあるが）と呼びた w。

もちろん現状でも多くのセンサーでインテリジェン 卜化に向けての改良が進んでいる。エンジンの吸入空 気量を計測する方式は種々実用化されているが，マニ ホールド圧力とエンジン回転数とから吸入空気量を推 定する方式は一種のソフトセンシングであり, 直接吸 入空気量が検出できない状況においては一種のインテ リジェント化でもある。このマニホールド圧力検出セ ンサーも, 最近の半導体技術の進歩を受けて大きく進 歩しつつある (表 2), (図 5 )。

またE F I フィードバックシステムでの $\mathrm{O}_{2}$ セン サーについても, 十分インテリジェントセンサーと呼 べる優れた機能を持っている。即ちその構造および特 性は図 6 および図 7 に示すが, 固体電解質であるジル コニアは高温では酸素イオンが両側の酸素濃度差に よって移動する性質がある。この酸素濃度差によって （1）式の起電力が発生する。

$$
\mathrm{E}=\frac{\mathrm{R} \mathrm{T}}{4 \mathrm{~F}} \quad \ln \frac{\mathrm{P}_{1}\left(\mathrm{O}_{2}\right)}{\mathrm{P}_{2}\left(\mathrm{O}_{2}\right)} \cdots
$$

この時, $\mathrm{E}$ は起電力, $\mathrm{P}_{1}\left(\mathrm{O}_{2}\right), \mathrm{P}_{2}\left(\mathrm{O}_{2}\right)$ は内側 (大気側）および外側（排気ガス側）の酸素分圧, $\mathrm{T}$ は素子温度， R， F は定数である。この式は本来空燃 比 $(\mathrm{A} / \mathrm{F})$ に対しては図 7 の点線の如き曲線 $\left(\mathrm{V}_{\mathrm{S}}{ }^{\prime}\right)$

表 2 マニホールド圧カセンサーのインテリジェント化

\begin{tabular}{|c|c|c|c|}
\hline 使用開始時期 & 圧カ検出手段 & 増 幅 回 路 & 他 の 機 能 \\
\hline 71 & ベローズ+差動トランス & ディスクリート & - \\
\hline 93 & 半導体ダイアフラム & H I C & - \\
\hline$' 87$ & $\uparrow$ & $\begin{array}{l}\text { ダイアフラムー体式 } \\
\text { +外付調整抵抗 }\end{array}$ & - \\
\hline 91 & $\uparrow$ & $\begin{array}{l}\text { ダイアフラムー体式 } \\
\text { +オンチップトリミング }\end{array}$ & - \\
\hline$?$ & $\uparrow$ & $\uparrow$ & A D C 付/温度センサー付 \\
\hline
\end{tabular}



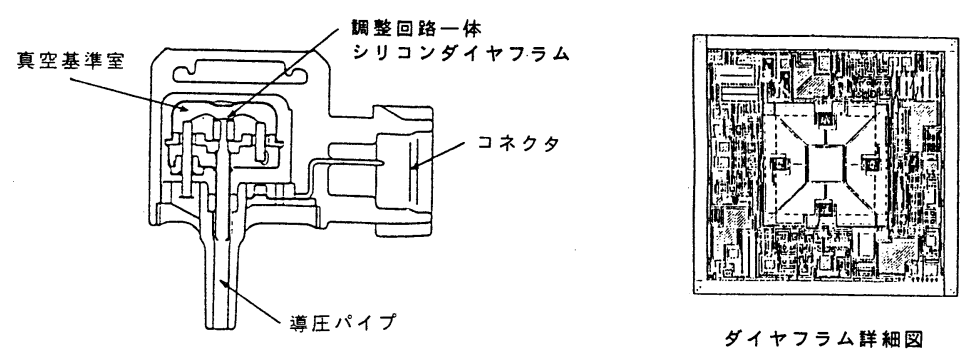

図 5 半導体圧カセンサーのインテリジェント化

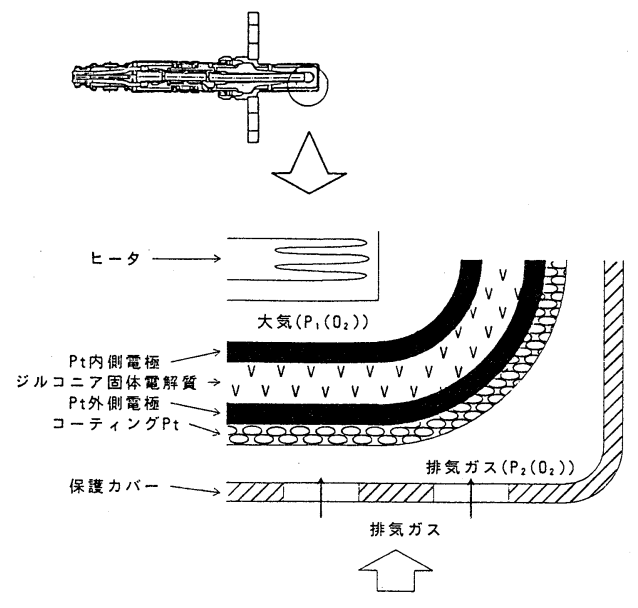

図 $6 \mathrm{O}_{2}$ センサー構造

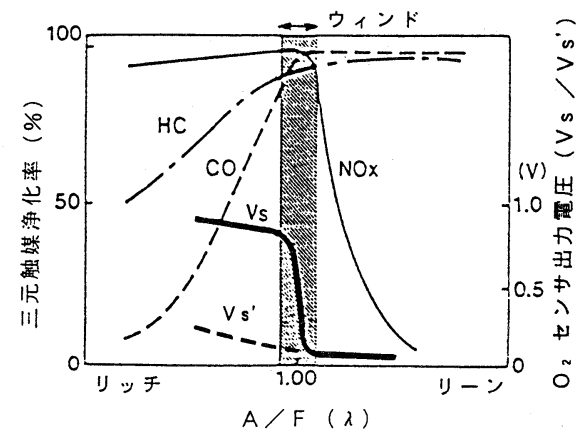

図 $7 \mathrm{O}_{2}$ センサー特性

である。

$\mathrm{H} \mathrm{C}, \mathrm{CO}$ 扔よびN Ox の三成分ともに浄化する能 力のある三元触媒の浄化率特性は図 7 のようになって おり，三成分ともに高い浄化率が得られるのは，空気 過剩率 $(\lambda)$ の $\lambda=1$ 付近のせまいウインドの範囲内 に限られる。 $\mathrm{O}_{2}$ センサーのコーティング層の厚みや ポロシティを適当に設けて，排気ガスの外側電極への 侵入をコントロールすることによって，外側白金電極
部での酸素分圧 $\mathrm{P}_{2}\left(\mathrm{O}_{2}\right)$ は, エンジンでの燃焼時の $\mathrm{A}$ /Fによって，リーンの時（ $\lambda$ が1より大きい時）は $10^{-1}$ 気圧程度の值になる。それが $\lambda=1$ の点を境にし てリッチ側（ $\lambda$ が1より小さい時）では $10^{-20}$ 気圧程 度まで急檄に小さい值になる。この結果式(1)の起電 力 $\mathrm{E}$ は $\lambda=1$ の点を境に図 7 の実線 $\left(\mathrm{V}_{\mathrm{S}}\right)$ の様に急 変する。(これを Z 特性という) この特性を利用して $\lambda=1$ 付近の 3 成分とも高い浄化率を示す三元触媒の ウインド内にエンジンの $\mathrm{A} / \mathrm{F}$ を制御するフィード バックシステムが成立する。

さらに燃費対策の観点から, リーンバーンシステム が検討されているが，このシステムのキーになるのが リーンミクスチャセンサーである。トヨ夕の開発した リーンミクスチャセンサーの構造を図 8 に示す。その 動作原理は図 9 に示す如く, ジルコニア素子に電圧を 印加して酸素ポンプセルを構成し，排気ガス側にかな り緻密なコーテング層を作ってガスの拡散律速層とし, 排気ガス中の酸素分圧（これが $\mathrm{A} / \mathrm{F}$ に比例する）に 比例した電流（限界電流 I ）が流れることを利用して, $\mathrm{A} / \mathrm{F}$ を検出する様にしたものである（図10）。これ もメカニカルではあるが, 優れたインテリジェントセ ンサーである。

最近のエンジン制御においては，この燃料量制御に 加えて点火制御，アイドルスピード制御，燃料ポンプ

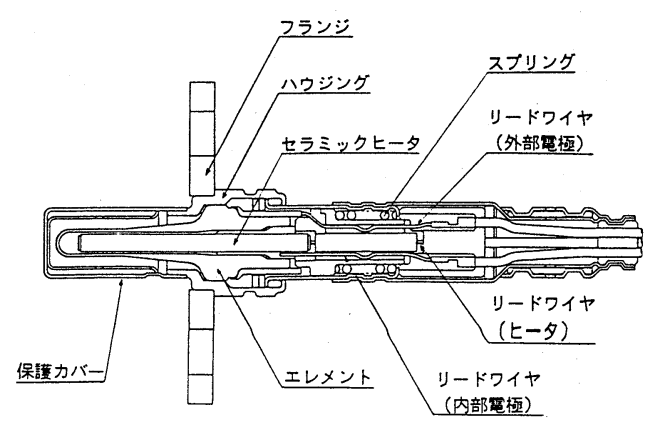

図 8 リーンミクスチャセンサー構造 


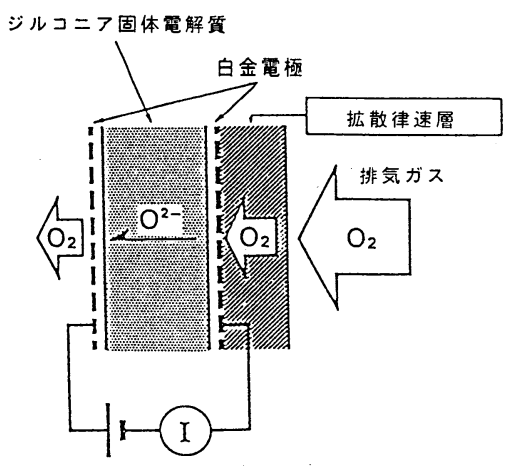

図 9 作動原理図

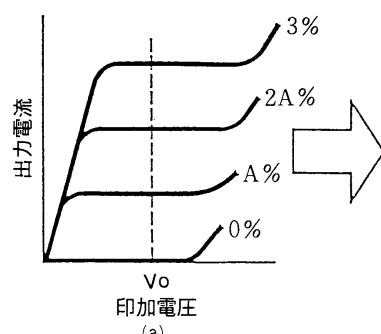

(a)

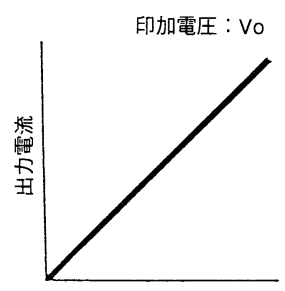

排気側 $\mathrm{O}_{2}$ 濃度

(b)

図10 リーンミクスチャセンサーの出力特性

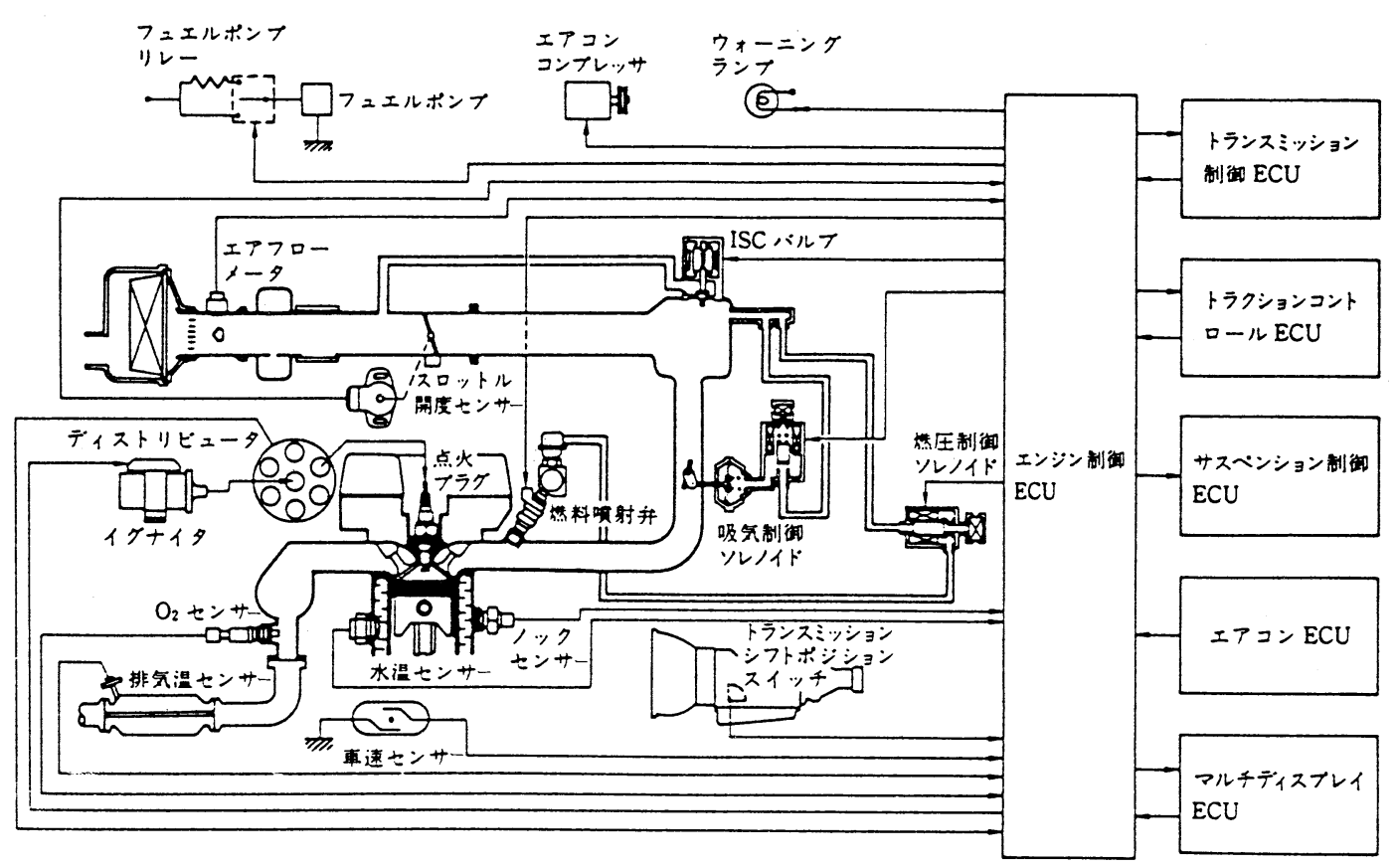

図11 エンジン制御をベースにした車両総合制御

回転数制御， E G R 制御等，他のエンジン制御機能を 総合化しつつあり, さらに最近ではオートマチックト ランスミッション制御やシャシ制御などとも連携した 車両総合制御へと進みつつある（図11）。

\section{2 シャシ分野}

エンジンの分野で先行したカーエレクトロニクスは 近年その分野を拡大し, シャシの分野に扔いても活発 である。シャシ技術はそれまではバネや油圧を用いた 八イドロメカニカルやニューマチックメカニカルなシ ステムが多かったが, 操縦安定性と乗り心地の両立要 求, 安全性向上の追求, さらには快適性, 便利性への
気運の高まり等から A B S （アンチロックブレーキシ ステム), T E M S (ショックアブソーバ減衰力制御 システム)，アクティブサスペンション，電子制御パ ワーステアリング等, シャシのあらゆる分野でエレク トロニクス制御化が進んでいる。

このシステムのエレクトロニクス化に伴い, 種々の センサーが開発されているが, 初期の E F I の頃とは 違って，センサー技術がかなり進歩していた為，当初 からかなりインテリジェント化したものも作られてい る。

例えばエアサスペンション用の車高センサー（図 


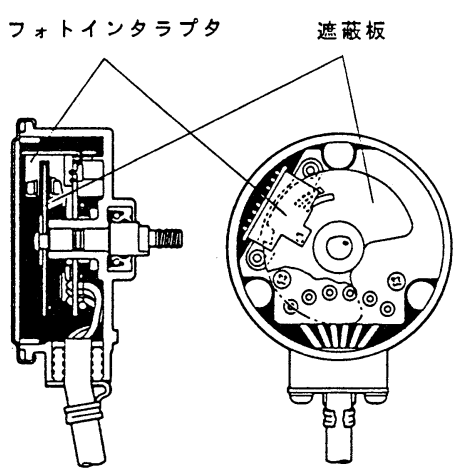

図12 エアサスペンション用ハイトセンサー

12）はフォトインタラプタと, 軸と一体回転する遮光 板によって 4 bit のグレーコードを出力するように なっている。さらに 4 bit のパラレルデータをシリア ルデー夕に変換する I Cを組み込んだものも製品化さ れている。

減衰力可変システムではバネ上の上下振動を制御す

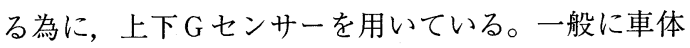
（バネ上）に発生する上下振動は， $2 \mathrm{~Hz}$ 以下ではフ ワフワとしたあ扮り感となり， $2 \mathrm{~Hz}$ 以上ではゴッゴ ツとした感じとなる。そこで通常はソフトに設定して
ゴツゴツ感を抑えておき， $2 \mathrm{~Hz}$ 以下の振動に対して 減衰力をハードに切り換えるようにしたい。この為, ここで用いる Gセンサーとして，4次のローパスフィ ルタ $(-24 \mathrm{~dB} /$ Oct $)$ と増幅回路を内蔵して高い周 波数選択性を持たせている。

一方トヨタで開発したピエゾT E M S は, ピエゾ素 子の持つ高速応答性を応用した新しい概念の減衰力可 変システムである。これは通常時の設定をハードとし て高い操縦性，安定性を確保しておき，路面の突起や 段差に差しかかってショックアブソーバが変位し始め ると，ピエゾセンサーが高応答にそれを検知し，ピエ ゾアクチュエータが高応答に反応して，隇衰力をソフ トに切り替えて乗り心地を良くしている。これなどは 本来検出の極めて困難であったショックアブソーバの 減衰力を直接計測することを可能としたピエゾセン サーによるところが大きく，センサーの機能としては まだ単に荷重の計測のみに過ぎないが，新しい機能材 料の応用によって可能になったものであり，これもイ ンテリジェントセンサーと呼べる（図13）。

\section{3 ボデー制御分野}

人々の社会生活が豊かになるにつれて, 快適性や便 利性への要求も高まってゆく。いちいちドアの鍵穴へ キーを差し込まなくても施錠, 解錠のできるキーレス

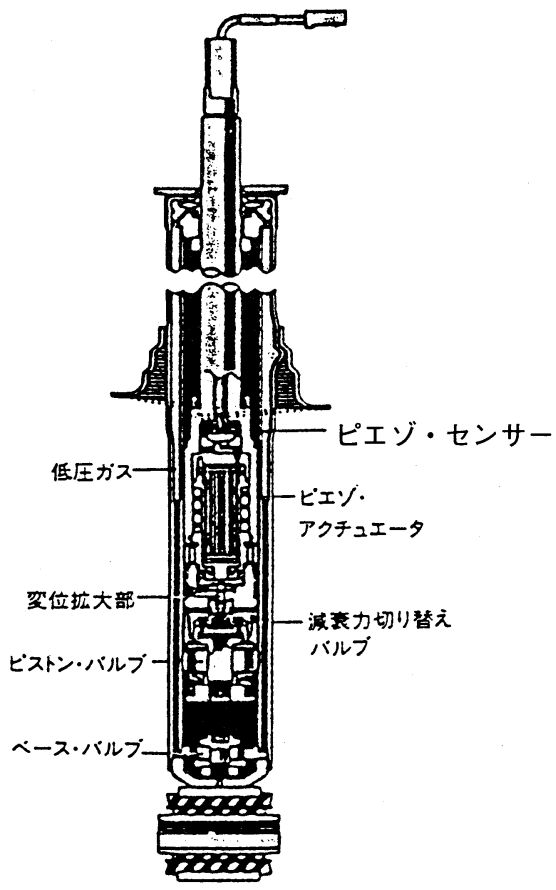

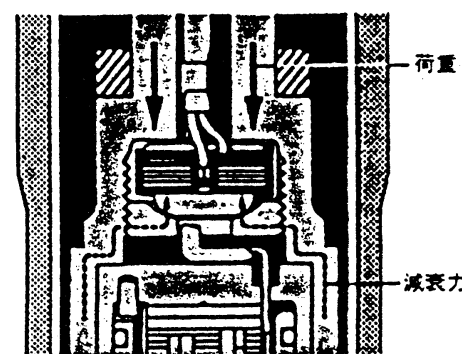

センサー部拡大図 
エントリ，自分に最も合ったポジションにシートの位 置やハンドル角度等を調節してくれる各種メモリ機能, 車を後退させる時, 後方の障害物を超音波で検知し知 らせてくれるバックソナー等多くのボデーエレクトロ ニクスシステムが実用化されている。

また近年交通安全への社会的要求の高まりから, 衝 突時の車体減速度を検知して, シートベルトをロック したり，エアバッグをふくらませて乗員を保護しょう とするシステムも一般化しつつある。

言うまでもなく，これらのシステムを実現させる為 にも多くのセンサーが開発されて抢り，この分野のセ ンサーにおいてもインテリジェント化が進みつつある。 エアバッグ用 $G$ センサーはメカニカル式と半導体式 とがある(図14,15)。メカニカル式は衝突 Gレベル を質量の移動で検知するとともに，バネ定数の設定に よりそのレベルを判定し, 火薬の着火をも担当するセ ンサーで, エレクトロニクスは使っていないが優れた インテリジェントセンサーである。一方半導体式の $\mathrm{G}$ センサーは, 現在単に車体の減速度を検出するのみで, 信号処理, レベル判定, 火薬への通電等は別のコント ローラーが担当しており，メカニカル式に比べると，

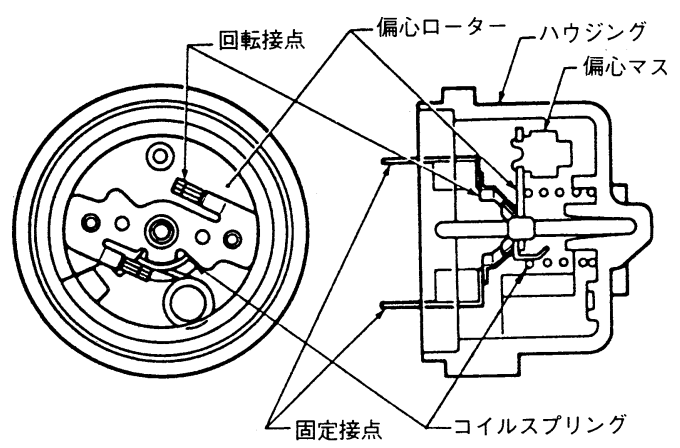

図14 エアバッグ用Gセンサー（メカニカル式）

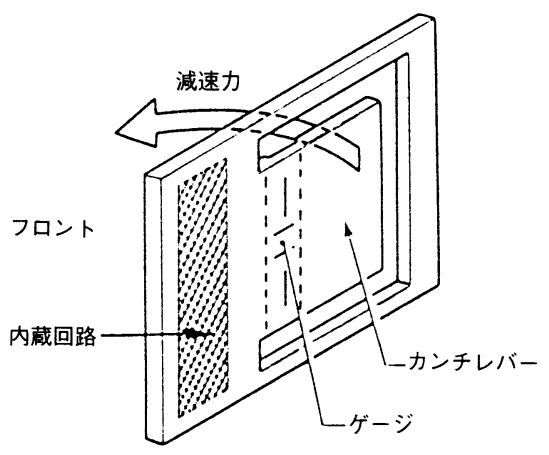

図15 エアバッグ用Gセンサー (半導体式)
ここでもセンサーのインテリジェント化の面では一歩 後退の感があるが, 半導体式Gセンサーは, 故障診断 や，異なる車両への適合の自由度が高い等，今後のイ ンテリジェント化のポテンシャルは高い。

近年スピードメータのケーブルレス化が進んでいる。 トランスミッションの回転をスピードメータケーブル により計器盤まで機械的に取り回すことは, 重量の面 や配索性, さらに騒音の面でも課題が多かった。これ をトランスミッションに直接車速センサーを取り付け て回転信号として取り出すことにより解決しようとし たものである。ここでも初期には電磁ピックアップ方 式が一般的であったが，最近ではマグネットを回転さ せ, 新しい機能材料のM R E (磁気抵抗素子) を用い て検出し, 波形整形を行って耐ノイズ性を向上させて インテリジェント化を図っている。

車外の明るさや対向車のヘッドランプ光等によって 自車のヘッドランプやテールランプを点滅したり, 減 光したりするコンライトシステムは, かなり古くから 実用化されている。これに用いられる光検知センサー （図16）はフォトダイオードと信号処理回路を内蔵し たもので, 現在は薄暮検出や夜間検出, 夕イマ機能等 は別体の E C Uが担当しているが，半導体技術や実装 技術が進めば，これらを一体化したインテリジェント センサーとなる可能性も高い。

その他オートワイパの為の雨センサー, エアコンの より快適制御化の為の日射センサーや各種温度セン サー, オーディオのダイバシティアンテナやノイズ キャンセラ等, この分野は自動車と乗員との関係や乗 員の感性に直接影響するシステムが多いという意味に おいて, 今後ますます優れたインテリジェントセン サーが生まれて来る分野である。

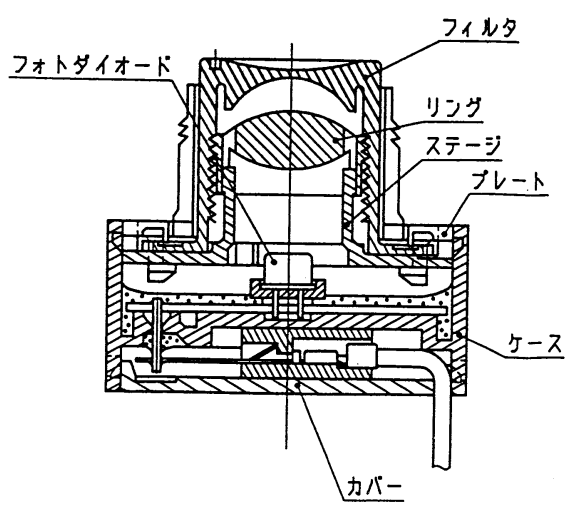

図16 コンライト用光検知センサー 


\section{3. 今後の動向}

自動車がますます社会性の高い商品となり, 人々が ますますその高機能化，高性能化を求めるのに伴い, 自動車の各種システムも進化し, 発展する。また自動 車は極めて幅の広い総合産業であり, 他業界の技術進 歩も取り込みながら変質する。

半導体技術の進歩が, 大型コンピューターをミニコ ン化，さらにはパソコン化したり，通信技術がサテラ イト通信を可能にしたり，パーソナル電話を可能にし ている。オフィスオートメーションは大きなビルをイ ンテリジェント化しつつある。さらに最近のマイクロ マシニング技術は, 直径 $100 \mu \mathrm{m}$ のモー夕や, 直径 80 $\mu \mathrm{m}$ のダイアフラムを可能にしつつある。

このような状況の中で, 自動車のシステムおよびそ れらを支えるセンサーはどの様に進歩するのだろうか。

自動車の個々のシステムの機能が向上するのに加え, 各々のシステム同志が連携をとって，トータルにより 高い性能を引き出す総合制御化に向かう。これに対応 して重要になるのがインテリジェントセンシングであ る。

良いセンサーノアクチュエータがシステムの機能や ポテンシャルを左右することは前にも述べたが，これ まで述べた様に現状のセンサーレベルは，インテリ ジェントセンシングとして期待されるレベルからする と,まだ従来のインテリジェント化された巧みなセン サーのレベルに達しているものは少ない。

自動車の基本性能制御分野において, 正確な出力卜 ルクセンシング, 正確な対地速度センシング, また姿 勢制御に最も重要な車体のヨーモーメントセンシング など, システムの要求する基本的物理量の直接センシ ングが望まれる。

今後は直接センシングに加えて, 総合制御における 車内通信技術の進歩に伴い, ソフトセンシング技術も 大幅に進むと期待される。

図17は従来から提案されているインテリジェントセ ンサーの一つの概念図であるが，これのみにとらわれ ず急速に進歩する半導体技術，マイクロマシニング技

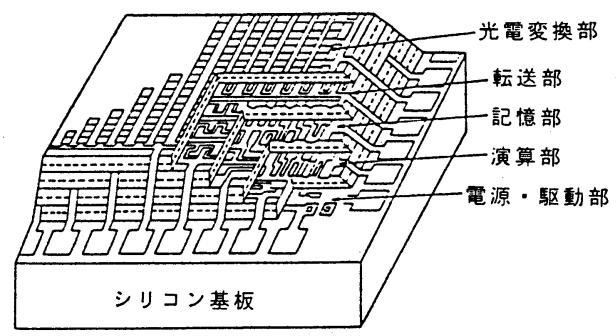

図17３次元インテリジェントセンサー概念図

術，材料技術，通信技術などを駆使して，従来のメカ ニカルな優れたインテリジェントセンサーを越えた真 のインテリジェントセンシングを期待したい。

\section{文献}

1) Ina, O.," Recent Intelligent Seneser Technology in Japan” SAE 891709

2) Numazawa, A., "Automotive Electronics in Passenger Cars” Proc. Int. Conf. on Transportation (1988)

$3)$ Ono, H.,"Electronic Engine and Driveline Management" SAE Australia Seminar (1988)

4 ）沼澤 明男, “自動車排ガス用ジルコニア酸素セ ンサー” Ceramic Science and Technology at the Present and in Future 1981

5 ) Akatsuka, T.,"Development of Lean Mixture Sensor for Toyota lean combustion system" ISATA 85044

6 ）吉川 勇夫, “自動車エレクトロニクスの現状と 将来” 精密工学会誌，55，(5)，(1989）

7 ) 広瀬 正典, 中野 次郎, “電子機能素子の車載 センサー・アクチュエータへの応用” 自動車技術, 44, (9), (1990)

8 ) Aburaya, T.,“Development of an Electronic Control System for Active Suspension" Proceedings of the 29 th IEEE Conference on Decision and Control (1990) 